\title{
The boundary shifters of North Western Kenya
}

\author{
Beneah M. Mutsotso \\ Department of Sociology and Social Work, University of Nairobi, P. O. Box 30197 - 00100 Nairobi, Kenya.
}

Accepted 27 March, 2018

\begin{abstract}
Shifting of ethnic and/or administrative boundaries is a subject of concern in North Western Kenya. The paper presents the formal and the informal pictures of the contested and often shifted boundaries as well as the current justification in each case. The paper presents that the creation of ethnic boundaries in 1932-34 enhanced ethnic consciousness, a factor that now determines access to public services. The contest over boundaries should be understood from the background of ethnicity. Use of archival sources and primary data are combined to provide historical and contemporary perspectives. Boundary shifting is a common factor in this region pitting pastoralists against pastoralists, pastoralists against agro-pastoralists and even further agro-pastoralists versus agro-pastoralists with consequent disruption of livelihoods. Finally the paper recommends the avenue for resolving the problem of boundary shifting in the region.
\end{abstract}

Keywords: Boundary, ethnic, administrative, conflict, shifting.

E-mail: bmutsotso@yahoo.com.

\section{INTRODUCTION}

\section{North Western Kenya region}

The North Western region of Kenya is made up of several administrative and political counties. In this region administrative and ethnic boundaries are more pronounced than in most parts of the country. They are Nandi, UasinGishu, Trans Nzoia, Elgeyo-Marakwet, West Pokot, Baringo, Samburu and Turkana. In this area are found several ethnic groups with varying levels of compatibilities and incompatibilities. For this paper the focus is on the communities living in the counties of West Pokot, Turkana and Baringo. They are: Pokot, Turkana, Tugen and II Chamus ethnic groups. The Pokot and Turkana are pastoralists while the Tugen and II Chamus are agro-pastoralists. The Pokot ethnic group occupies the central region in relation to all other ethnic groups hence boundary shifting affects them, and they affect it, from multiple fronts. The north western region generally suffers from developmental maladies the most prominent of which are: low access to education and health, drought and famine, violence occasioned by cattle rustling and disputed boundaries. The north western region also borders Uganda to the West, South Sudan to the North West and Ethiopia to the North. In the colonial period between 1895 and 1963, and after independence in 1963 the region was and remains marginalized politically, economically and in all aspects of development (Weiss, 2006). Part of the marginalization is attributed to the long distance from the capital city of Nairobi especially since 1963 (GoK, 2013).

The north western region is rife with insecurity. Cross border raids between the Pokot and Turkana against Ugandan, South Sudanese and Ethiopian communities is common and often without government intervention. International boundaries and national administrative boundaries are either not marked, poorly marked or simply ignored leading to considerable contest and conflict between the ethnic groups. The boundary conflicts are even farther motivated by absence or insufficient government presence (GoK, 2010).

The north western part of Kenya is awash with small arms which are obtained from a variety of sources including South Sudan, Somalia, Ethiopia and Uganda (TJRC, 2013). Each community is forced to arm itself for protection given the inability or unwillingness by the central government to provide protection (Pkalya et al., 2003).

The north western Kenya region was part of the 
northern frontier region, a closed-area-policy imposed by the colonial government which subsequently isolated it from the rest of the country. Later the kipande (pass) system was imposed on the residents of this region and on others who wished to travel to this area. The government did little if any investments in this region as the people were labeled anti-development, hostile, fierce or warlike (GoK, 2010). The problem of disputed boundaries and the magnitude of the consequences with little or no government intervention to address it is a reflection of their historical exclusion.

One of the bold attempts to address the underdevelopment malady in north western Kenya was through a recent constitutional provision. The Constitution of Kenya promulgated in 2010 recognizes communities that had been excluded from national social and economic life for different reasons. In Article 260 it defines marginalized communities and marginalized groups as follows: (a) as a community that has a small population and for this reason it has not been able to fully participate in the social and economic life of Kenya, (b) a traditional community out of need to preserve its unique culture and identity from assimilation has remained outside the national activities (c) an indigenous community that has retained and maintained a traditional lifestyle and livelihood based on a hunter-gatherer economy (d) pastoral communities whether nomadic or settled and because of geographic isolation have experienced marginal participation in the integrated social and economic life of Kenya.

Therefore disadvantaged communities are identified with a particular geographic location and their members identify with each other culturally. Although the constitution does not explicitly define the concept marginalized areas, it implicitly refers to a geographic location where significant populations of marginalized communities live (GoK, 2013). Article 204(3) of the constitution requires that the national government uses the Equalization Fund (which is $0.5 \%$ of total government revenue) to provide grants to counties where marginalized communities live. Hence West Pokot, Baringo, and Turkana counties were to benefit from this Fund to ameliorate for the historical deficiencies, but from 2013 the Fund has never been disbursed for the purpose for which it was created thereby farther marginalizing the region. The fund has been bedeviled with squabbles between national government, county government and members of parliament from the respective counties on which of the three entities were best placed to manage it. The impasse contributed to its delayed disbursement. In addition there were no guidelines on how to identify and fund priority projects.

The history of exclusion of north western Kenya from the mainstream is also accounted for by discriminatory legislation and policy. For instance the District Ordinance Act of 1902 created the "closed districts" policy for Turkana, West Pokot and Samburu counties while the
East Pokot region of Baringo district was just ignored. It required a pass to move in and out of the districts. Therefore for a long time an exclusionist policy was pursued hence further marginalizing the area.

The Sessional Paper No. 10 of 1965 which formed the foundation for development in Kenya emphasized investment of resources in areas of high economic potential in order to attain rapid economic growth. This policy inevitably led to neglect of non-agricultural areas of which North Western region was part. Therefore the problem of un-marked, poorly marked or imposed boundaries should be seen as part of the marginalization as such areas were found to be of less or no value to the state.

\section{METHODOLOGY}

The background to the preparation of this paper adopted a triangulated methods approach in both collection and analysis (Jick, 1979). This article draws partly on data from fieldwork conducted by the author from February 2016 to July 2017 in parts of the counties of Baringo, West Pokot, Samburu and Turkana. Most of the time was however spent in Baringo county given its greater ethnic diversity and its central geographical location visavis other counties. The data collection involved a number of field trips to the north western region of Kenya often ranging from two to four weeks per trip. In total, seven trips were made within the time period. Hence the data and information presented here is partly based on the interviews and discussions with 213 individuals, individually or in groups. Most of the data collected was through qualitative methods including key informant interviews, in-depth interviews, focus group discussions and direct observation. The data was not nor strived to make it representative of the entire population in the respective counties but rather it was collected on a broader scale based on experiences and perceptions with a clear focus on age, gender, location and ethnicity. In other words, apart from the county administrative leadership the concentration of interviews was among communities living in the shifting or shifted boundary areas.

The interviews were conducted in manyattas (traditional homesteads, kraals, shops with male and female elders, male and female youth). In addition, government officers, security personnel in contested areas, business people and staff from civil society organizations were interviewed in their offices, stations or shops. Enlisted from each ethnic group were the services of two (one male, one female) local educated youths who helped in translation. They also knew quite well the safe routes as well as areas to avoid during data collection. The use of local youth made it unnecessary to undertake prior community mobilization. However in all the counties, the county administration was notified beforehand. The 
administration in turn notified the chiefs or assistant chiefs in charge of the areas; the mission of the study was sampled as well as to ensure safety. Key informants were interviewed individually but were asked not to be present in any other subsequent interviews. During field interviews observation of contested or shifted boundary areas and in some areas beacons was made. This made me realize that shifted boundaries, in some cases, made one ethnic group acquire or loose pasture or farmland in an areas spanning as wide as $30 \mathrm{~km}$ radius. In some cases a line of make-shift shops, road or a stream was the basis of the boundary dispute. This gave me a firsthand impression of the scale and complexity of boundary shifting in the north western region of Kenya. Given the sensitivity of boundary shifting and what it stood for in the context of livestock keeping, care was taken not to divulge any information provided by any respondent to another one.

In order to buttress the primary data, a historical review was undertaken. This took me to the Kenya National Archives to comb through records in order to get a clearer picture of the history of ethnic boundary making in the region. In order to get this, I relied mainly on District Annual Reports, Intelligence reports and letters of correspondence from 1910-1962 for Baringo, Samburu, West Pokot and Turkana. The documents showed details of ethnic boundaries, the representatives from each ethnic group who were witnesses and actual locations where beacons were pegged. The archival information provided valuable data on the position of the official boundaries vis-a-vis the informal/shifted ones.

This approach enabled me to obtain boundary claims from each ethnic group (in their current view) compared with the official one described in government books. It was realized that there were great variances in all cases.

\section{MARKING OF ETHNIC/ADMINISTRATIVE BOUNDARIES IN KENYA}

In the $19^{\text {th }}$ century, the area that is called Kenya today was stateless and its peoples' civility and ethnicity were largely shaped by means of livelihood (Lonsdale, 1992). Therefore ethnic boundaries are foreign creations imposed on the people. The first attempts at boundary marking were by the Devonshire White Paper of 1923 which created the white highlands as separate from native reserves (Maxon, 1991, 1993). However, the boldest attempt by government to make administrative boundaries (which were largely ethnic boundaries) rests with the Carter Commission of 1932-34. The work of this commission created ethnic consciousness in Kenya for the first time as ethnic groups were made to realize that they were different from others. One of the Commissions' terms of reference was to determine native African claims to land (whether occupied by whites or not) and to make recommendations for their fair settlement. The resultant ethnic enclaves were christened districts from 1934 until 2010. The Commissions' report also declared that the boundaries were securely set and could not be altered by local means.

In 2010 Kenya promulgated a new constitution which then christened the districts as counties (GoK, 2010). Section 6(1) of the constitution provides that Kenya is divided into counties. The constitution in its preamble proclaims that Kenyans are proud of their ethnic and cultural diversity and they live in an indivisible nation. Article 7 defines both the national and official languages in Kenya as unifying factors but also protects the diversity of languages. Article 10 provides for national unity and inclusivity. Article 11 highlights culture as the foundation of the nation. In addition, the constitution in principle frowns upon discrimination on the basis of ethnicity.

However, the initial bisection of the country based on ethnic groups aroused ethnic consciousness. The district then and now made it easier for ethnic mobilization and more importantly the practice of divide and rule (Elkins, 2008). Burbidge and Cheeseman (2017) made it that ethnicity has a negative impact on intercommunal trust. It is now clear that ethnic boundaries helped to raise the level of common knowledge. Common knowledge defined as that which occurs when every person knows what every person knows, and knows that they know it (Rasmussen, 2001). It is therefore no wonder that ethnicity is more pronounced in Kenya (due to creation of boundaries) compared to Tanzania for instance (Miguel, 2004). To a considerable degree, ethnicity now defines access to public and communal services and a barrier to inter-ethnic coordination in socially heterogeneous areas (Miguel, 2004). The denial of public services to the pastoralist Pokot who occupy Nadome section of Turkana county should be understood from this perspective. Mueller (2008) discussed the political angle of ethnicity in Kenya in which he found that ethnic groups (often living in a distinct administrative county) are themselves effective voting blocks and in a way help to promote ethnicity and access to public services.

\section{The fluidity administrative boundaries}

The issue of contested administrative boundaries ranging from either being unmarked, shifted, imposed, unclear and therefore fluid is a contemporary issue in the north western part of Kenya. This concern was earlier presented by Greiner (2013) whose focus was on the ethnic groups in Baringo county. This paper focuses on boundary disputes and boundary shifting on a regional perspective. Perhaps nowhere else in Kenya is the issue of fluid, contested boundaries, drawing and re-drawing more pronounced than in the north western region. The result has been systematic ethnic conflict leading to devastating consequences and loss of livelihood on a regional scale. Each community in the region claims the 
neighboring community has shifted its original boundary to its advantage and to the disadvantage of the other.

In Kenyan history, official ethnic/administrative boundary marking was done in 1932 by the famous Carter Land Commission (GoK, 1932). The government of Kenya (then) on realization of continued ethnic conflict over territory formed the commission to draw the ethnic boundaries which also served an administrative purpose. It required each community to present its claim(s) before the commission. Consequently each community was shown or allocated its land and the boundaries clearly marked with beacons.

In spite of this clarity, boundary disputes continue to be the cause of a considerable source of conflict between the ethnic communities that inhabit the region. The complexity of the current ethnic claims and shifting is as follows: The Pokot ethnic group accuse the Turkana, Tugen, Samburu and/or II Chamus ethnic groups to have shifted the boundary to their advantage. The II Chamus ethnic group claims the Pokot have encroached on their territory thereby shifted the boundary. Similarly the Turkana claim the Pokot have shifted their boundary to include parts of Turkana territory. The Pokot and Tugen both claim Loruk trading centre which falls within their boundaries. The discovery of mineral resources e.g. geothermal in Loruk and Mount Silale, diatomite in Kositei, oil in Turkana South and the construction of the Turkwel Gorge dam in Pokot North and the benefits that accrue from these resources escalated the boundary disputes (Knchr, 2017). In some cases boundary disputes and the resultant shifting have been fueled by politicians (Greiner, 2013).

In 2010, the Government of Kenya formed the Interim Independent Boundaries Review Commission (IIBRC, 2010) which identified the main cause of boundary disputes in the country to be: unfair boundary definition, informal boundary review, alteration of political boundaries, insecurity, organized violent groups, water sources and multiplicity of cultures in the boundary areas. In the north western region the IIBRC (2010) identified the following contested or shifted boundaries: TurkanaPokot boundary stretching from Kapedo to Kacheliba; the Kapsait / Kasagar area between the Pokot and Marakwet; the Pokot- II Chamus boundary at Mukutani, Pokot-Samburu boundary at Amaya; the Pokot-Tugen boundary at Loruk and the Turkana-Pokot area of Kapedo market centre. The IBRC (2010) also noted international border disputes in Turkana North between Kenya and South Sudan and, Kenya and Ethiopia governments.

Presented subsequently are the details of the specific boundary disputes and the consequent shifting between the different ethnic groups. In each case, the official boundary definition based on official government archival records of 1932 are presented and thereafter follow up with the informal boundary claims, shifts and/or alterations. In one case, the boundary dispute has had an unsuccessful legal redress.

\section{Specific boundary disputes in north western Kenya}

\section{The fluid Pokot-II Chamus boundary at Mukutani}

The Mukutani area boundary dispute is between the East Pokot ethnic group and the II Chamus ethnic group. The GoK (1920) defined the Pokot-II Chamus boundary as marked by latitude $0^{\circ} 40^{\prime}$. A map was drawn to show the exact boundary. A review of archival records at the Kenya National Archives showed that the Pokot-II Chamus boundary at Mukutani was eventually demarcated in 1924 (GoK, 1924). The GoK (1932) report noted as follows:

The Land Commission visited Kabarnet in September 1932 and took evidence. The II Chamus ethnic group appealed for an area on top of the Laikipia escarpment between Mt Ng'elecha and River Mukutani and it was granted.

Mukutani centre was initially created on the banks of River Mukutani in 1907 in order to effectively arbitrate the competing conflict over water and pasture between the Pokot and II Chamus (Anderson, 2002). The Pokot used the pastures to the north of River Mukutani while the II Chamus used pastures to the south (Little, 1992). Based on the official records and other recorded evidence the Pokot-II Chamus boundary is River Mukutani with the Pokot occupying the northern side and the II Chamus to the South of River Mukutani. However, from the mid 1980 s to the present the boundary is contested and has been re-drawn severally and informally often in favor of the II Chamus ethnic group. Similarly the Pokot have redrawn their version of the boundary in the area. Interviews with Pokot and II Chamus respondents yielded opposed views on the exact location of the boundary. The IIChamus claim is that the Pokot boundary is nine kilometers to the north of River Mukutani while the Pokot insist Mukutani river as the boundary.

Interviews with a Pokot respondent ${ }^{1}$ on this topic yielded the following response:

The wife of the II Chamus chief was a nurse at Mukutani health centre which is to the North of the River. The chief then relocated his home to the Northern side from the South of the river. He used to hold his meetings to the north. So the chief and his II Chamus people assumed that his jurisdiction was on both sides of the River Mukutani. He only lived to the North while his jurisdiction was confined to the South of the river. To the North is for the Pokot people.

Another Pokot interviewee ${ }^{2}$ said the following'

\footnotetext{
${ }^{1}$ Pokot witness interviewed at Mukutani Village about $1 \mathrm{~km}$ from the Mukutani shops (Mr Jones Losikiriatum, a pseudo name).
} 
Mukutani Primary school and Mukutani Health centre are adjacent and to the north of the River. The retired President Moi transferred Mukutani Primary school to II Chamus and the Health centre remained with us.

An II Chamus respondent ${ }^{3}$ was categorical that their boundary was not marked by the River Mukutani. He said,

The Divisional Officer from Marigat came to Mukutani and showed us where our boundary with Pokot was. It is nine kilometers to the North of River Mukutani.

The conflict over the correct location of the boundary even led to the withdrawal of the government officer (Divisional Officer) who had been posted to Mukutani Centre from the II Chamus sub district of Marigat. The Pokot contested the posting and even threatened to shoot the officer and burn his vehicle. This prompted the government to quickly withdraw the officer and shelve the posting. The Pokot contest was based on the fear that the administrative action was a ploy to legitimize the II Chamus incursion onto their territory (Knchr, 2017).

The informal boundary shifting has led to the violent displacement of most II Chamus community from the larger Mukutani area estimated at $99 \%$ (Knchr, 2017). As a result, thousands of acres of pasture-land, irrigation farms and infrastructure, crops and schools were destroyed or abandoned leading to the rise of thousands of internally displaced persons in camps along the shores of Lake Baringo at Kiserian area. In its wake, there arose the no-man's land, an expansive but uninhabited area separating the Pokot from the II Chamus. The no-man's land underscores the seriousness of fluid boundaries in the north western region.

\section{The moving Pokot-Samburu boundary at Amaya}

The Pokot - Samburu boundary was defined in 1924 (GoK, 1924). A review of archival materials describes and implies the boundary as follows:

A Turkana, Samburu and Kenya African Rifles party moved across Amaya river into Pokot territory and rounded up two other kraals (GoK, 1924).

This description demonstrates that the Amaya River officially marked the boundary between the two communities. The current contest on the boundary however is whether it is at Longewan village (about $8 \mathrm{~km}$ into Samburu county) as claimed by the Pokot ethnic group or it is marked by Amaya River as the Samburu

\footnotetext{
${ }^{2}$ An Il Chamus elder (Mr Alfred ole Pelu, a pseudo name)

${ }^{3}$ A Samburu chief of Longewan Location
}

ethnic group claim. In this case, the Pokot informally shifted and imposed the boundary into Samburu land. The Pokot claim to the new boundary area began in 2004 when many of them settled in Longewan village therefore demanded that the area they resided in was part of Pokot territory. The conflict over Amaya boundary led to the closure of Amaya Primary School, the collapse of Amaya Irrigation Scheme and withdrawal of Samburu students from Churo High School (Okumu, 2010). The disruption underscores the consequences of fluid boundaries as well as the apparent government in action to remedy the situation.

A Samburu respondent ${ }^{4}$ of Longewan informed the researcher as follows:

For all this time we have not had a problem with the Pokot until early 2000. Many Pokot moved and settled in our village of Longewan. We welcomed them. When they were many they began to say that Longewan was part of Pokot (therefore in Baringo county). They even refuse to report to our chief but go across the river Amaya to report to a Pokot chief instead. We have fought with them over this boundary but there is no solution in sight. The government is also silent. We cannot tell what the government and even our leaders are doing about it as they are silent.

\section{The shifting Pokot - Tugen boundary at Loruk}

The earliest Pokot-Tugen boundary was defined in 1916 following incessant conflicts over water and pasture. The government moved to define the boundary as follows:

The District Commissioner of Ravine visited the disputed area in person. He took the Pokot and Tugen elders over the boundary and showed them their respective areas. In 1920 the boundary was gazetted (GoK, 1916, 1920).

And further,

The District Commissioner met the Pokot at Loruk after they refused to destock (GoK, 1939).

The 1939 report implies the Pokot lived at Loruk where the District Commissioner met them to discuss the destocking problem.

The boundary issue over Loruk attained national limelight in 2010 when the Tugen member of parliament for Baringo North constituency publicly and unilaterally pronounced that the Tugen -Pokot boundary was not at Loruk trading centre but nine kilometers from Loruk into

\footnotetext{
${ }^{4}$ A Pokot resident of Apuke village near Turkwell Gorge Dam in west Pokot (Mr Chemariach Lokis, a pseudo name).
} 
Pokot land. However, the Pokot claim that their boundary with the Tugen at Loruk centre was marked by a dry river stream that cuts through the Loruk shops. The claim is that the old Loruk shops fall in Pokot while the new shops are in Tugen land.

The fluidity of Loruk boundary led to many deaths and 6000 people were displaced in 2010 and 2012 (Ndanyi, 2012). As it is, the boundary dispute remains unresolved and a frequent source of conflict, human displacement and loss of livelihoods. The discovery of geothermal potential at Loruk by government in early 2000 heightened the claims and entrenched the positions on both sides due to the anticipated benefits accruing from its exploitation. The discovery heightened the scope of shifting the boundary by both ethnic groups.

\section{The moving Pokot - Turkana boundary from Kapedo to Kacheliba}

A review of archival materials demonstrated that the entire Pokot-Turkana boundary as well as Kapedo centre was well defined and shown to the two ethnic groups. The GoK (1920, 1927) initially confirmed that the boundary was yet to be defined but shortly after that period it was marked. The GoK (1935) map for Baringo District showed Kapedo was part of Baringo District thereby implying its status had been determined. Kapedo centre was subsequently gazetted in 1933 as a trading centre via Government Notice No. 352 of May 25, 1933 under Baringo District. This definition was opposed by the Turkana as several conflicts continued on the entire boundary including Kapedo. In order to address the conflict over Kapedo in particular, a physical trace was marked in the market centre to clarify the boundary to the Pokot and Turkana ethnic groups (GoK, 1950). In addition, a standing Boundary Committee made up of Pokot and Turkana elders was formed to manage the boundary (GoK, 1951). The District Commissioners of Baringo (for Pokot) and Turkana District (for Turkana) and the Boundary Committee toured the boundary thereafter (GoK, 1952). The committee pacified the boundary disputes so that a subsequent meeting between the Pokot and Turkana ethnic groups at Kapedo in 1959 did not report any boundary problem (GoK, 1960).

The remaining Pokot-Turkana boundary from Kapedo centre westwards (about $130 \mathrm{~km}$ long) was finally defined by the government in 1932 as: A straight line from Kolosia to Tiati and the water course that leaves Kerio River upstream of Kolosia, and runs to Tiati but curving north (GoK, 1932).

Subsequent definition of the boundary in 1955 covered the Kolosia -Loiya - Kaputir stretch. The boundary was defined as follows;

The boundary runs to Lowiyapua on the Turkwel then by a water course to Loukwamuru at the foot of the Chemerongi range, then along the foothills southwards to Natholoi, then by River Aberrit to its confluence with Malmalt, then along Malmalt to Todotoro, then a water course to Lotongot, then by Lotongot - Kolosia road to Kerio, then upstream to Napawi. The Pokot and Turkana have agreed for so long on this large stretch of common boundary, it would be difficult altering its accepted position (GoK, 1955).

The entire Pokot-Turkana boundary marking was completed in February 1955 and those present during the marking process were: Assistant District Commissioners for Baringo and Turkana Districts accompanied by the Pokot and Turkana elders, chiefs and headmen on behalf of their respective communities. Since 1955 the boundary between the Pokot and Turkana has been fluid, shifting from position to position and from time to time.

The current conflict over the boundary is as follows: the Turkana have shifted the boundary and currently the entire of Kapedo centre and Silale Mountain are now part of Turkana territory. Similarly the Pokot claim that Kapedo centre and Mount Silale are both in Pokot region.

The second claim by the Turkana ethnic group is that their boundary is beyond River Weiwei (Malmalt River) up to Seker hills and Marich Pass therefore engulfing Turkwel Gorge complex, an area that stretches the boundary up to about $30 \mathrm{~km}$ inside Pokot land. At this level, the Pokot ethnic claim their boundary with the Turkana is $80 \mathrm{~km}$ from Weiwei River (Malmalt River) to Kalemng'orok region of Turkana. These two boundary claims are very fundamentalist and have led to thousands of losses of life and massive destruction of property and livelihoods. In this region, there is a clear pattern of the Pokot and Turkana communities attempting to appropriate from each other the water sources and the ever-green riverine pastures that are key to a pastoralist livelihood by shifting the boundary to their advantage. The Pokot and Turkana communities both claim ownership of the villages of Lorogon, Omblion and Apuke and the Turkwel Gorge Complex (Tomkou, 2013).

An attempt to have a political solution to the shifted Kapedo area boundary by the Pokot and Turkana politicians in 2015 did not succeed. This attempt was captured as follows;

The Turkana and Pokot politicians both presented documents in support of the claims that they were the genuine owners of Kapedo area - an 18 acre piece of land that has been identified as suitable for a geothermal power project, oil and gold exploration. A Pokot politician even threatened to lead the Pokot community to the African Court of Justice should the government fail to resolve the dispute (Odunga, 2015). 
In 2012, the Turkana politicians referred the Kapedo boundary dispute to the High Court of Kenya (eKLR, 2016). The matter is yet to be determined.

\section{The one people, two administrative jurisdictions phenomenon}

In most of the disputed boundary areas of north western Kenya, there is administrative overlap leading to poor quality or no access to government services. In other areas, government services have become ethnicized. Reliance on qualitative sources found the following intricacies and web of interactions in the region. At Loruk centre for instance, there are Tugen and Pokot chiefs who administer the same physical territory but superintend over members of their ethnic group only and report to different administrative/ethnic jurisdictions where their ethnic group is dominant. The Pokot chief reports to Chemolingot town which is the main Pokot administrative town to the east while the Tugen chief reports to Kabartonjo town which is a Tugen administrative centre. At Mukutani centre, the Pokot chief reports to Chemolingot while the II Chamus chief reports to Marigat, the main II Chamus town. At Kapedocentre, the Pokot chief reports to Chemolingot while the Turkana chief reports to Lodwar, the main Turkana town. In the western part of the shifting boundary area, the Turkana chief at Lorogon reports to Lodwar (about $300 \mathrm{~km}$ away) while the Pokot chief reports to Kapenguria town (about 150 $\mathrm{km}$ away). In all the cases the chiefs only provide services to members of their ethnic group. Equally, the people only recognize the chief who belongs to their ethnic group. The Pokot who live in Kapedo centre do not access Kapedo health centre for fear of the Turkana health staff hence prefer to go to Chemolingot hospital about $30 \mathrm{~km}$ away. Members of a particular ethnic group occupying an administrative territory of another ethnic group do not receive government services from the administration they are in conflict with. The most prominent victims of ethnicized government services are the Pokot who occupy a fringe Turkana East territory of Nadome. The Turkana administration in Lodwar town does not provide services to those people on the account that they belong to an ethnic group with whom they are in conflict.

The other intricacy is found in the education sector. The respective schools in the mobile boundary areas make their submissions to the county administration of their ethnic group. In addition pupils or students in each school belong to a particular ethnic group. There are no shared schools in shifting boundary areas. For example, Kapedo secondary school and Lorogon primary school have only Turkana learners, Longewan primary has only Samburu pupils, Turkwel primary has only Pokot pupils while Loruk only has Tugen pupils. Interviews with key informants in the border areas showed that in the political domain, the ethnicization of voter registration and voting was apparent. There were at least two voting streams in one polling station, each voting stream for a particular ethnic group. In one case a respondent lamented as follows:

Lorogon village is about four kilometres from the Turkana-Pokot boundary (Malmalt River) although it is the Turkana people who live in the village which is physically in Pokot land. However, during elections, Turkana politicians cross the boundary river into Pokot county to campaign among fellow Turkana voters. After voting, the votes are carried for over four kilometres from Pokot land and announced in Turkana County. This is how complicated the question of disputed boundaries has gone.

\section{CONCLUSION}

The phenomenon of informally redrawing and shifting boundaries is an issue of national concern in North Western Kenya. The constitution of Kenya gives the national government the power to draw, define and mark ethnic or administrative boundaries. The colonial government clearly discharged this function well. However, on the attainment of political independence in 1963 , boundaries were no longer respected as politicians informally altered them to the advantage of their ethnic group. Similarly, the elite from the respective ethnic groups have generated illegal google maps that depict large swatches of territories acquired from another group or contested shopping centres falling in the centre of another county.

A clear way out of this problem is to implement the recommendations of the IIBRC (2010) which stipulated the formation of an Administrative Boundaries Commission to resolve the teething problem which has been exploited by politicians and other ethnic elite to their advantage. In addition a bold programme on civic education would help to educate the people on boundary making and as well as respect for boundaries as they were drawn in 1932.

\section{REFERENCES}

Anderson, D. (2002). Eroding the Commons. The Politics of Ecology in Baringo, Kenya 1890 - 1963. James Currey, Oxford.

Burbidge, D., and Cheeseman, N. (2017). Trust, ethnicity and integrity in East Africa: Experimental evidence from Kenya and Tanzania. Journal of Race, Ethnicity and Politics, 2: 88-123.

eKLR (2016). Turkana county Government and 20 others vs Attorney General and Others.

Elkins, C. (2008). What is Tearing Kenya Apart? History of One Thing. Washington Post, January 6, 2008.

GoK (1916). Baringo District Annual Report. National Archives. Nairobi. GoK (1920). Baringo District Annual Report. National Archives. Nairobi.

GoK (1924). Baringo District Annual Report. National Archives. Nairobi.

GoK (1932). Baringo District Annual Report. National Archives. Nairobi.

GoK (1932). The Carter Land commission Report. National Archives. Nairobi.

GoK (1939). Baringo District Annual Report. National Archives. Nairobi. 
GoK (1951). Baringo District Annual Report. National Archives. Nairobi. GoK (1952). Baringo District Annual Report. National Archives. Nairobi. GoK (1955). Baringo District Annual Report. National Archives. Nairobi. GoK (2010). Report of the Committee of National Elders Conference on Cohesion and Integration. Ministry of Justice, National Cohesion and Constitutional Affairs. Government Printer. Nairobi.

GoK (2013). Policy on the Criteria for Identifying Marginalized Areas and Sharing of the Equalization Fund. Commission for Revenue Allocation. Nairobi.

Greiner, C. (2013). Guns, land and votes: Cattle rustling and the politics of boundary (re)making in Northern Kenya. African Affairs, 112(447): 216-237.

IIBRC (2010). Report of the Interim Independent Boundaries Review Commission: Delimitation of Constituencies and Recommendations on Local Authorities Electoral Units and Administrative Boundaries for Districts and other Units. Government Printer. Nairobi.

Jick, T. (1979). Mixing qualitative and quantitative methods. Triangulation in action. Administrative Science Quarterly, 24(4): 602611.

Knchr (2017). Interim Report of the Public Inquiry into the Conflict and Violations of Human rights in North Rift Region of Kenya. Nairobi.

Lonsdale, J. (1992). Unhappy Valley: Conflict in Kenya and Africa. James Currey, London.

Maxon, R. M. (1991). The Devonshire Declaration. The Myth of Missionary Intervention. History in Africa, 18: 259-270.

Maxon, R. M. (1993). The Struggle for Kenya: The Loss and Reassertion of Imperial Initiative 1912-1923. Fairleigh University Press.

Miguel, E. (2004). Tribe or nation? Nation building and public goods in Kenya versus Tanzania. World Politics, 56: 327-362.

Mueller, S. D. (2008). The political economy of Kenya's crisis. Journal of Eastern African Studies, 2(2): 185-210.

Ndanyi, M. M. (2012). Kenya: 6000 flee Home as Pokot-Tugen Tensions Rise. The Star, Nairobi. http://alafrican.com/.

Odunga, D. (2015). Fear of Losing Seats Fanning Border Rows. Sunday Nation, February 15, p. 25 Nairobi.

Okumu, W. (2010) Youth Led Peace Caravans and Inter-Community Peace Building among Pastoralists in North-Western Kenya. African centre for the constructive Resolution of Disputes. South Africa.

Rasmussen, E. (2001). Games and Information: An Introduction to Game Theory. Blackwell. Oxford.

TJRC (2013) Final Report of the Truth Justice and Reconciliation Commission of Kenya. Volume 11B. Nairobi.

Tomkou, M. (2013). Turkana Clans Wars a Hot Potato. Daily Nation December 2013.

Weiss, T. (2006). Guns in the Borderlands, North Rift Institute for Security Studies. Pretoria.
Citation: Mutsotso, B. M. (2018). The boundary shifters of North Western Kenya. Net Journal of Social Sciences, 6(1): 1-8. 